\title{
Laser hearing aids
}

\author{
Gentiana Wenzel", Hubert Lim, Kaiyin Zhang, Sven Balster, Ole Massow, Holger Lubatschowski, Guenter Reuter, \\ Thomas Lenarz \\ From 2nd Scientific Meeting of the Head and Neck Optical Diagnostics Society \\ San Francisco, CA, USA. 23-24 January 2010
}

Visible light is a source of energy known to activate the visual system through absorption by photoreceptors in the eye. When the so-called stress-confinement condition is fulfilled, laser light can induce an acoustic signal through an optoacoustic effect. We sought to assess, if visible light with parameters that induce an optoacoustic effect (i.e., $532 \mathrm{~nm}, 10 \mathrm{~ns}$ pulses) could be used to stimulate the peripheral hearing organ at ear drum and middle ear level.

Auditory brainstem responses (ABRs) were recorded preoperatively in anesthetized guinea pigs to confirm normal hearing. After opening the bulla, a $50-\mu \mathrm{m}$ core-diameter optical fiber was positioned first in the outer ear canal directed towards the tympanic membrane and then within the bulla directed towards the bony structures within the middle ear as well as towards the round window membrane.

Optically-induced ABRs (OABRs), similar in shape to those of acoustic stimulation, were elicited with single pulses after stimulation within the outer as well as the middle ear. The OABR peaks increased with energy level $(0.6-23 \mu \mathrm{J} / \mathrm{pulse})$ but varied in magnitude depending on the location of stimulation.

Our findings demonstrate that visible light can be used to activate the peripheral hearing organ when applied at the ear drum level or on bony structures within the middle ear that can transmit vibrations to the cochlea or inner ear. We propose that this novel, noncontact laser stimulation method could be used to improve implantable and non-implantable hearing aids as well as for research purposes.

Published: 29 October 2010

doi:10.1186/1758-3284-2-S1-O31

Cite this article as: Wenzel et al:: Laser hearing aids. Head \& Neck Oncology 2010 2(Suppl 1):O31.

Medizinische Hochschule Hannover, Hannover, Germany
Submit your next manuscript to BioMed Central and take full advantage of:

- Convenient online submission

- Thorough peer review

- No space constraints or color figure charges

- Immediate publication on acceptance

- Inclusion in PubMed, CAS, Scopus and Google Scholar

- Research which is freely available for redistribution

Submit your manuscript at www.biomedcentral.com/submit
C Biomed Central 